\title{
Lintu kämmenelläni
}

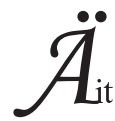

i, ennen niin vahva nainen. Pitänyt aina itsensä ja toiset pystyssä. Nyt hän on kuin hauras lintu. Miten kannattelisin häntä, jonka tuessa minä olen aina ollut? Helvetillinen ristiriita. Haluan auttaa, tukea. En osaa, en löydä väylää hänen luoksensa, ei ole yhteistä kieltä. Äiti lepää avuttomana minun kämmenelläni. Asetelma on outo, vieras.

Kun saavun, seisoo hän eteisessä vanha ja risainen villapusero päällään. Ennen niin vahvat ja tummanruskeat hiukset roikkuvat harmaina, ohuina ja suorina pitkin poskia. Hän on lähdössä tavanomaiselle matkalleen roskalaatikolle - kauppaan - takaisin. Tarjoudun viemään jäteastiat ja tarkistan jääkaapin käydäkseni samalla kaupassa. Poistan totuttuun tapaani kaikki vanhentuneet ruuat ja vilkaisen vielä pakastimeen.

- Miksi täällä on näin valtavasti jäätelöpurkkeja, kysyn hämmästellen?

- Ajattelin että on mitä tarjota, jos te lapset tulette käymään, vastaa äitini ihmetellen kysymystäni.

Mieleeni palaa lapsuus, kuumat kesät ja jäätelötötteröt. Muistan, miten kuljin ystäväni Annen ja siskoni Tarjan kanssa Linnanmäen kallioiden keskeltä Jordanvirraksi ristimämme paskaojan reunaa pitkin Eläintarhanpuistoon, jossa järjestettiin päivätoimintaa kaupungin lapsille. Jokaisella piti olla omat astiat, juomat ja eväspalaset, mutta hernekeiton ja mannavellin tarjosi kaupunki. Jordanvirran mädäntynyt lemu sekoittui heinäkuussa kukkivien lehmusten huumaavan imelään tuoksuun. Päivät kuluivat leikkien.

- Aletaanko tervapataa, minä voin jäädä, kaikuu puistikossa ja pian vaihtaa tikku tiheästi paikkaansa ringissä.

Kävimme joskus ryhmän kanssa myös uimastadikalla. Minua ei olisi saanut altaasta millään, olinhan varsinainen vesipeto jo pienenä.

- Niin olitkin, keskeyttää äiti muisteluni. Muistan kuinka putosit rattaista Brahen puiston altaaseen. Tarja tuli sitten iloisena kertomaan, että äiti katso kun Irma ui. Siellä sinä makasit altaan pohjalla silmät sepposen selällään. Siitä alkoivat uinti- reissusi. Paluumatkalla Eltsusta pysähdyimme aina kioskille, siihen Lintsin alapuolelle ja kaivoin 50 pennisen taskustani.

Muistan nuo päivät kauniina, päärynätötteröltä maistuvina.

Istumme keittiön pöydän ääressä ja äitini kertoo tarinoita omasta lapsuudestaan. Siitä, miten hän oli juossut metsään ja heittäytynyt pensaikkoon suojautuakseen ryssien ankarilta pommituksilta. Saksalaiset sotilaat ostivat hänen isänsä teurastamosta lihaa ja maitotuotteita antaen pois lähtiessään lapsille makeisia ja suklaata, jotka olivat haluttuja tavaroita noina puutteellisina aikoina. Äitini perheellä ei ollut koskaan pula ruuasta, tarpeet kohdistuivat muihin asioihin: kahviin, tupakkaan, sokeriin... Niihin jotka olivat kortilla sodan aikana. Äitini muistot ja näkökulma sotaan ovat toisenlaiset kuin olivat isällä, joka humalassa vuodatti rintamamuistoja ja tuputti ryssävihaa minkä kerkisi.

Isä oli toki muutakin kuin jenkkejä kannattava ja sodasta kiihkoileva jaarittelija. Äiti oli tavannut hänet 1954 Alppilavalla ja ihastunut heti tuohon Menneniltä tuoksuvaan tummaan ja hauskaan lieksalaismieheen.

- Lavalla kaikuivat sävelet, "Metsään on tullut jo syys, lohduton yön hämäryys. Vaan hongat huokaillessaan suojaavat kukkia maan."

Äitini kuvailee elävästi sitä, kuinka hän oli suorastaan lentänyt tuon parkettien partaveitsen käsivarsilla. Sen jälkeen ei edes silloisella miesystävällä ollut asiaa parketille hänen kanssaan, saatikka että äiti olisi kelpuuttanut miesparkaa enää saatille. Voin hyvin uskoa sen, sillä valssasin usein isän jalkojen päällä pyörähdellen ja täytyy myöntää, että tanssin taidon hän hallitsi. Seuraavaksi muistelemme äitini oppikouluun pyrkimistä. Päähänpiston seurauksena ei hän noussutkaan $\mathrm{Ou}$ luun menevään linja-autoon, vaan maleksi kylillä miettien samalla miten olisi kertonut vanhemmilleen, että jänisti pääsykokeista. Hän on monesti elämänsä varrella katunut tuota tekoa.

Äiti muistaa kaikki pikkukohdatkin menneisyy- 
destään, mutta eilistä päivää ja sovittuja asioita ei sitten millään. Ei sitä, että on maksanut laskun toistamiseen tai että on nauttinut juuri päivälääkkeet ja joutuu tarkistamaan dosettinsa yhä uudestaan ja uudestaan.

Hän selittää minulle, kuinka ei ole elämänsä aikana voinut parhaimmille ystävilleenkään kertoa painavimpia huoliaan ja pyytää heiltä apua. Ei ole halunnut eikä kehdannut. Tuo kaikki kuulostaa oudolta, koska olen itse saanut aina tukea ja auttanut myös muita. Olemme käyneet monesti kiivaita väittelyjä siitä, pitäisikö minun puolustaa ja auttaa hädässä olevia ystäviäni, vai ei. Hänen mielestään tehtävä kuuluisi perheenjäsenille tai pikemminkin tulisi jokaisen selviytyä vastoinkäymisistään itse. Siksi tuntuukin oudolta ja vieraalta, miten hän yhtäkkiä on riippuvainen muista. Miten hän ei selviydy arkisista askareista, joihin ei vielä muutama kuukausi sitten olisi halunnut millään apua. Muistan äidin vannoneen, ettei hän vanhana jättäydy kenenkään vaivoiksi, vaan hakeutuu vanhainkotiin. Nyt ovat ajatukset muuttuneet.

Äitini yli viidenkymmenen vuoden aikainen ja rakkain ystävä Eine kuoli marraskuussa 2007. Ehkäpä odotetusti kylläkin, mutta sydänystävän menetys sai äitini pois tolaltaan. Yli viisikymmentä vuotta ystävyyttä - siihen mahtuu jo melkoisesti. Yhteys omiin ystäviini on kestänyt vain muutamia vuosia. Minun ihmiseni ovat tulleet ja menneet elämäni aikana. Pienimuotoisessa muistotilaisuudessa piirsimme muotoa Einestä mielessämme. Lasten oli ollut vaikea löytää muistotilaisuutta varteen yhtään valokuvaa, jossa äitini ei olisi ollut mukana. Tuo kuvaa hyvin sitä, miten äitini oli kaikissa perheen tapahtumissa läsnä, kuten Einekin meidän perheessämme. Tuo vuolaspuheinen ja aina niin naurava nainen ei piitannut ulkoisista asioista, tavaroista, rahasta, ei vaatteilla koreilusta. Hän otti elämän varjot ja ilonpisarat sellaisina kuin ne vastaan tulivat. Eine rakasti ihmisiä ja arvosti elämää.

Äidillä on varmasti valtava ikävä tuota naista ja kaikkia poismenneitä rakkaitaan. Lähestulkoon kaikki äitini ystävät ovat siirtyneet ajasta ikuisuuteen ja rakkaimman ystävän poismeno oli viimeinen piste äidilleni. Tuosta alkoi ajanjakso, joka on ollut kaikille osapuolille raskas, hämmentävä ja keinoton.

Maailmalla huokaillaan kauhistuneina kiihtyvästä ilmaston muutoksesta, presidentti Bush vierailee ympäri Lähi-itâä ja Vantaan Hakunilassa hiihdetään kilpaa sohjon ja vesisateen keskellä suo- menmestaruuksista. Samaan aikaan kärsii Suurmetsän betonilähiössä pieni Iissä syntynyt vanhus masennuksesta ja turvattomuudesta. Olemme hankkineet sisareni kanssa monenlaista apua äidille: ateriapalvelun, siivouspalvelun, kotisairaanhoitajan, joka jakaa lääkkeet, auttaa pesuissa ja seuraa verenpainetta sekä verensokeriarvoja. Erittäin asiantunteva, aito ja empaattinen terveydenhoitaja on ammattitaidollaan ja lämpöisellä ihmisyydellään auttanut myös meitä sisaruksia äitimme tukemisessa ja omassakin selviytymisessämme. Seuraavaksi yritämme saada äidilleni jotain mielekästä päivätoimintaa, jotta arkeen tulisi jotain sisältöä. Pahimpaan ja suurinta osaa vanhuksia koskevaan ongelmaan, yksinäisyyteen eivät nuo keinot ylety.

Äiti on mennyt paniikissa keskellä yötä useiden naapureidensa luo ja yöpynyt heidän sohvillaan.

Arvostan sitä, että samassa talossa 35 vuotta asuneet naapurit pitävät huolta toisistaan, mutta heidän apunsa ei ratkaise ongelmia. Jo harvaksi käyneet tutu ovat kaikonneet eivätkä naapuritkaan enää aukaise hänelle oveaan. On helppoa olla vastaamatta, kun näkee soittajan ja ovisilmästä kolkuttajan. Tuntuu kuin mitkään keinot eivät auttaisi, vaan päivittäin ilmaantuu yhä uusia ongelmia.

- Aivan kuin edellämme vyöryisi lumipallo, jota mikään ei pysäytä.

Äidillä on jatkuva hätä ja huoli. Hän on hukassa omassa kodissaan. Eksynyt itsestään.

- Miltähän tuntuisi herätä ja huomata tavaroiden ja huonekalujen vaihtaneen paikkaansa joka yö?

Näin kehitysvammaisia hoitaneena huomaan hänen käytöksessään samoja piirteitä, kuin on autisteilla. Hänen keskittymiskykynsä on alentunut, kiinnostuksen kohteet vähentyneet radikaalisti ja asioiden merkitysten ymmärtäminen rajoittunut. Kaikki pitää olla muuttumatonta, strukturoitua ja tapahtua aina samalla kellon lyömällä. Jo pieninkin muutos aiheuttaa paniikkia, ahdistusta ja pelkoa. Pelkoa, turvattomuutta ja muistin katoamista hän yrittää hallita rutiineilla ja tavaroilla. Esimerkiksi nukkumaanmeno vaatii monenlaisia järjestelyjä, useista vesilaseista, vierelle asetetuista tyynyistä ja levitetyistä nenäliinoista lähtien. Pienistäkin asioista luopuminen, kuten viimeksi ammeesta, merkitsee luopumista omasta itsestä ja jälleen osasta senhetkistä pärjäämistä. Ne ovat lopullisuuden merkkejä, jotka saavat hänet surulliseksi. 
Tuo lakkaamaton paha olo vain kärjistyy illan ja yön saapuessa. Hän pelkää nukahtamista. Uskon kuoleman pelon vallanneen äitini, jonka vuoksi hän ei uskalla olla yksin kotona. Kenties jo kulman takana vaanivasta kuolemasta puhuminenkin tuntuu vaikealta, joten siitä keskustellaan vain sivulauseissa. Eräänä yönä sain hätääntyneen puhelun äidiltäni ja jouduin soittamaan apua, kun hän oli sekoittanut vuorokauden ajat ja napannut suuhunsa jo seuraavankin aamun lääkearsenaalin.

Siinä jälleen uusi ongelma, johon on löydettävä ratkaisu. Vielä kesällä 2007 siivosi hän kolme huonetta käsittävän asuntonsa, puisteli suuren mattomäärän, kävi saunassa ja ammeessa, kokkasi itselleen ja vieraille, liikkui itsenäisesti pitempiäkin matkoja ja huolehti raha-asioistaan ilman toisten apua. Nyt on tuki tarpeen. Pitää täysin paikkansa, että ihminen tulee vanhana lapseksi jälleen. Riippuvaiseksi toisista.

Huomaan, miten hänen luonteensa ja persoonallisuutensa kaventuvat, ja miten mielenkiinto ympäristöä kohtaan laimenee. Keskustelut pyörivät menneessä, yhä harvemmin nykyisyydessä. Ymmärrän, että on mukavampaa puhua ajanjaksoista, jotka olivat vielä tapahtumia, ystäviä ja aktiviteettejä täynnä. Niistä ajoista, joista hänellä on selkeä kuva mielessään.
Äiti saattaa soittaa minulle kaksikymmentä kertaa päivässä, jopa öisin.

- Täällä on niin yksinäistä ja paha olla, kaikki ystävät ovat kadonneet. Täällä on niin yksinäistä ja paha olla...

Olen stressaantunut, masentunut, vihainenkin kaikesta. En haluaisi olla tässä tilanteessa. Tunnen syyllisyyttä siitä, etten aina jaksa kuunnella, ymmärtää samoja asioita toistavaa ja kurjaa oloa sekä yksinäisyyttä valittavaa äitiäni. Haluaisin paeta tilanteesta. Olen uupunut ja keinoton. Omaa elämääni ja voimavarojanikin haluan ajatella. Katselen ilmeetöntä ja eleetöntä läheistäni, joka pala palalta kuihtuu pois. Teen surutyötä. Jätän hyvästejä itsenäiselle ja voimakastahtoiselle äidilleni, tietämättä, mitä hänestä jää dementian edetessä jäljelle. Kun hänen mielessään ei ole enää mitään, jonka voisimme jakaa yhdessä? Mihin tilanteisiin minut vielä laitetaankaan? Missä on suureen ääneen kuuluttamani empatia? Ei, kyllä tämä on jotain suurempaa kuin kykyä asettua hänen asemaansa.

Tämä on pyyntö. Velka on maksettava. On minun vuoroni.

Irma Puumalainen osallistui tekstillään Lintu kämmenellä vuonna 2008 kirjoituskilpailuun Elämänmuutos. 